Please do not remove this page

RMIT

UNIVERSITY

\title{
Towards better recognising 'community' in multi-owned property law and living
}

Leshinsky, Rebecca; Mouat, Clare

https://researchrepository.rmit.edu.au/esploro/outputs/9921862433601341/filesAndLinks?institution=61RMIT_INST\&index=null

Leshinsky, R., \& Mouat, C. (2015). Towards better recognising "community" in multi-owned property law and living. International Journal of Housing Markets and Analysis, 8(4), 1-501.

https://doi.org/10.1108/IJHMA-07-2015-0031

Document Version: Accepted Manuscript

Published Version: https://doi.org/10.1108/IJHMA-07-2015-0031

Repository homepage: https://researchrepository.rmit.edu.au

(c) Emerald Group Publishing Limited

Downloaded On 2023/04/27 00:15:42 +1000

Please do not remove this page 
Thank you for downloading this document from the RMIT Research Repository.

The RMIT Research Repository is an open access database showcasing the research outputs of RMIT University researchers.

RMIT Research Repository:http://researchbank.rmit.edu.au/

\section{Citation:}

Leshinsky, J and Mouat, C 2015, 'Towards better recognising 'community' in multi-owned property law and living', International Journal of Housing Markets and Analysis, vol. 8, no. 4, pp. 1-15.

See this record in the RMIT Research Repository at:

https://researchbank.rmit.edu.au/view/rmit:32762

Version: Accepted Manuscript

Copyright Statement: (c) Emerald Group Publishing Limited

Link to Published Version:

http://www.emeraldinsight.com/doi/pdfplus/10.1108/JJHMA-07-2015-0031 


\title{
Towards better recognising 'community' in multi-owned property law and living
}

\begin{abstract}
Introduction
The rapid growth of Multi Owned Properties (MOP) results in vertically tenured communities of residents and workers that test contemporary best practices in policy, governance and legal regulation. Growth pressure worsens deficits of recognising communities in land-use planning and law reform. As emergency services need to anticipate disasters and plan for evacuation, authorities need to know the detailed building location, building height, and resident-worker population of any given part of the city especially in the high-rise inner city. However the everyday life, work, and play of these very same occupying populations remains mostly unknown. Land-use planners and policy makers perpetually struggle to recognise these communities, engage them in deliberat(iv)e decisions, and determining how best to intervene with 'effective, morally-acceptable policy responses' (Kenna and Stevenson, 2010; Warr and Robson, 2013; Wolf-Powers, 2014, p. 202). Clearly many planners and regulators understand that recognising (the diversities and demography of) community is critical to empowering citizens and to address existing urban tensions and sustainability challenges in our post-industrial urbanism (Bailey, 2010). Yet few municipalities hold sufficient demographic data or working knowledge on existing or emerging vertically tenured communities. This results in a tendency for blind, reactionary, and aspirational responses in law and planning policy with few measures of effectiveness. Despite evidence of innovative practices moving from piecemeal to more coordinated community engagement (Margerum, 2011), the identity and relational politics of community remains problematic and elusive (Kenna and Stevenson, 2010; Maller and Nicholls, 2013; Shaw, 2008). Persistent political inattention as city skylines rise is counterproductive to a more robust understanding of community as a social sustainability catalyst and for anchoring inclusive, diverse and just city development (Fainstein, 2010). Alternatively, untangling the MOP urbanism spectrum offers rich insights: firstly, into the complex theories and practices framing socially sustainable cosmopolitan co-existence as equitable and collective; and secondly, into more effective policy and urban governance processes across strategic and everyday conditions.
\end{abstract}

This article responds to calls for more co-ordinated and transdisciplinary MOP research agendas (Dredge and Coiacetto, 2011; Lees, 2012). Efforts to co-ordinate and contextualise these concerns via the inaugural multidisciplinary MOP colloquium held at Deakin University in Melbourne (February 2015) resulted in this special issue. Drawing together interested researchers, the colloquium tackled the gamut of challenges from finding common terminology to transdisciplinary lessons. This article adds to this coalescing dynamic by showcasing hotspot socio-legal MOP issues that resonate with broader necessity for land-use planning both for the public city and private community. Comparing international cases, the article shows how the collaborative engagement approaches and reform priorities regulating MOP are exemplified in repercussions for civic law and strategic metropolitan policy already grappling with intensifying urbanism.

To this end, empirical evidence is taken from internationally recognised best practice in MOP living and law from the Canadian province of Ontario, and the Australian state of Victoria. The case for better recognising the issues and affects for MOP community are examined through the private condominium market ${ }^{1}$ experiences and community concerns seen through

\footnotetext{
${ }^{1}$ In most global housing markets now, arguably due to neoliberal influences, it is understood that condominium refers to the private ownership of a lot (unit) and a shared interest in the common property (lifts, stairwell, swimming pool, grounds, and games room) (Blandy,
} 
public engagement processes for law reform, and dispute resolution in case law. This research champions the further work required to recognise and interrogate who lives in MOP communities and differences in how they are socio-politically constituted and performed within and beyond MOP condominiums.

A holistic recognition of community across governance contexts is pursued. This article firstly canvasses MOP literature where community is recognised within extant legal and landuse planning instruments and processes. Secondly, it showcases a theory-building typology methodology (after Doty and Glick, 1994). This approach frames and synthesises essential elements in recognising community in MOP: from design and nature of theoretical bases; typological modelling; to empirical testing of ideal and hybrid constructs exercised by government and planners. Thirdly, typological analysis acknowledges the idiosyncrasies of two different city and national contexts. Further content analysis allows finer-grained analysis. The comparative Ontarian-Victorian findings relating to identity and relational politics are analysed for rewarding reciprocal insights into emerging urban governance practices. Recognising socially sustainable community provides more effective knowledge and opportunities to understand ordinary and transferable key MOP issues and challenges facing policy-makers and communities. Fourthly, data analysis from the law reform process and the legal case law tests ideal concepts to recast key MOP issues and challenges: as publically identified (in categories classified by Ontario law and policy reformers) and as identified by the researchers (in the case law and our wider analysis). Finally, as vertically tenured communities continue to flourish globally and locally, it discusses corresponding hard lessons (derived from and informing rigorous policy and law reform) and softer learnings (practical wisdoms of affective encounters engaging with and living in MOP) for professional and lay-folk. The article concludes with recommendations for further study into gaining insight into the social sustainability of vertically tenured MOP community.

\section{Talking a whole new approach to community in MOP urbanism}

Overcoming deficits in recognising MOP community includes the dynamics underwriting evolving urbanism and governance. Marking and bridging this deficit requires greater holistic and comparative attention in public and academic forums than presently pursued. Past studies on MOP emphasise classification of dispute issues, single issue topics, historical and life cycle evaluations and social disadvantage in housing (Blandy et al., 2010; Douglas, Leshinsky, and Goodman, 2009; Easthope et al., 2012). There is a growing trend for MOP analysis to move beyond limited insights related to conventional housing market analysis and home ownership (Ariff and Davies, 2011; Randolph and Tice, 2013). Still others are embracing transdisciplinary learning - between social mix and gentrification studies and the policy transfer/mobility process, for example (Lees, 2012) - and spell out specific research agendas to better inform MOP service management (Levy and Sim, 2014) and planning practices (Dredge and Coiacetto, 2011). Further, there is an emerging coalescing of knowledge fragments addressing the limits and opportunities within intensified urbanism. Urban literature offers powerful research inquiry relating to children in apartments (Easthope and Tice, 2011; Sherry, 2008), contradictory developer narratives (Fincher, 2007), and recognising the limitations of density in urban structure and form in relation to sustainability potential (Grosvenor and O'Neill, 2014). Accordingly, our holistic appreciation of community as variously used in law and living is timely; especially considering the power mechanisms (Flyvbjerg, 2004) exercised in reproducing a robust diversity of social sustainability and

Dupuis, and Dixon, 2010; Davies and Atkinson, 2012). In Australia, such tenure was known (mostly) as strata. Over time this has changed to encompass condominium-style private ownership but in Australia there is still no legal ownership term as 'condominium'. 
personal-collective affects across the diverse private and public communities of Western neoliberal cities.

MOPs model and reproduce a distinct public community of residents around a private commons characterising an intensified urbanism in often-sprawling cities. Each MOP community is cauterised from wider community through unique regulations for each MOP complex; and caused through wider political economy and the privatised reproduction of the city exemplified in the international political economy of 'condo-ism' (Rosen and Walks, 2013). Condo-ism 'refers simultaneously to self-reinforcing processes re-producing intensification, downtown living, and gentrification via condominium living as well as to the financial-construction nexus at the heart of condominium development and the social, cultural and political transformations that they are begetting' (Rosen and Walks, 2013, p. 160). Globally, condo-ism is unevenly manifest within and between many Western cities from downtown to suburban (re)development. Condo-ism highlights the pivotal distinction between historical high-rise social housing and current trends gentrifying urban consolidation in private MOP living. Shifting developer narratives target middle and upper income households typifying the private (re)production of the private city in contrast to those attending the historical tenancies by lower-income in public housing (Fincher, 2007). The holistic approach endorses diversity as socially sustainable ethos. Yet it cautions where extent and intensity of privately reproducing the city results in either yawning dichotomies of citadels and ghettos or homogenising suburban MOP sprawl. Thus the article champions 'the opportunity to radically rethink the terms of community' in MOP amidst 'the progressive implementation of compact urban development via urban intensification, globalisation, and the increasing diversity of lifestyles and ethnicities in the $21^{\text {st }}$ century cosmopolis' (Sandercock, 2003). Under these conditions reproducing a just city and socially sustainable community demands a political sophistication that existing conventions and models cannot provide (Mouat, 2010, p. 203).

Such sophistication is especially vital when the enduring conventional responses campaign to reduce urban sprawl pressures in material ways. Material responses very often focus on housing as artefact or systems by focussing on intensifying physical design or masterplanning lifestyle; structural provision systems; and managing developer supply restrictions from apartment to city-regional metropolitan planning (Gleeson, 2004; Palmer, 2014). Material responses mean that economics and design often dominate urban policy attention (Dempsey et al., 2011; Ibrahim, 2011) neglecting the social and political (Huston and Darchen, 2014). Moreover the reliance on law (reform) and regulatory engagement means that government agencies tend to operate with singular poorly differentiated and instrumentally discrete understandings of community. For example, statutory requirements or good practice of community and community participation can vary significantly by jurisdiction or legal purpose (from infrastructure, environmental protection, or special purpose). This discretionary fragmentation and variation undermines any uniform process of constituting and empowering communities. However, a holistic approach appreciates complexity under extreme and everyday conditions of intensified urbanism, austerity, climate change adaptation and advanced neo-liberalisation. Notably, Dempsey et al. (2011) explore the socio-material relationship between density, urban form and social sustainability in UK cities where social sustainability comprises elements of environmental and 'social equity' and 'sustainability of community'. Consequently we can observe that both materially and politically MOP communities act as a sophisticated fractal of urban vitality. They reflect larger concerns operating at the public-private city and residential interface (Pløger, 2006). 
By addressing the public (re)production of sustainable living in private MOP settings better, urban models and socially-sustainable outcomes can and must be negotiated.

This means that public (re)production of MOP community ranges from law to governance and living with plenty of overlapping, competing, and uneven geographies of encounter, engagement, and co-existence. Ownership constitutes re-producing a public domain and engagement that is hoped for by law reformers, developers, and policy makers, and variably appreciated by owners, tenants and neighbours. Currently MOP community is a by-product of a material residential purchase or investment, where negotiation is more likely at MOP board meetings, or when owners are in dispute, for example. Notably tenants, particularly in the Australian context, are excluded from this formal reckoning. Thus MOP ownership constitutes a financial and social buy-in to a discrete community urbanism including commons provision, utility, and maintenance. The dissonance between lifestyle marketing and real experiences of MOP community law and living may be mitigated by good law and governance. Various resident experiences have been shown to be powerfully shaped by governance structure (Kenna and Stevenson, 2010) and legal process (Goodman and Douglas, 2010). Materially, the cohesive inclusive community ideal tends to be codified and then forsaken or lost in building post-industrial 'anywhere architecture', suburban sprawl, and poorly-adapted travelling policy discourses such as new urbanism or condo-ism. Moreover, technological and aesthetic solutions of ecologically designed 5-star green-rated buildings commonly precede the challenges for occupants of educative and relational elements of community co-existence. Without ongoing political discussion in public commons and law reform, the adaptive and hospitable ethics of neighbours and community are powerfully framed but poorly served by even the best-scripted laws and MOP rules and by-laws.

For tenants, property manager, and policy professionals, recognising and negotiating community as tenure-long learning is a neglected priority. This capacity requires both systematic and ordinary attention to the characterisation of and conflict in community as it plays out. The agendas of policies and laws powerfully shape and are shaped by how community is wholly or partially recognised in various contexts and conditions. These act as benchmarks for strengths and weaknesses for a mutual and ongoing aspiration towards achieving synergies of just and inclusive communities. Experiences in the current best practice status of Canadian and Australian MOP law and living, as reported here, expose the challenges need law reform but also that capacity-building perpetually needs a holistic and wise recognition of the fuzzy and overlapping domains of community.

\section{Towards a theory-building typological approach: a restricted typology of MOP issues}

This article uses content and typological analysis to develop a theory-building typology (following Doty and Glick, 1994; O'Raghallaigh et al., 2010; 2012). 'Typological analysis is a strategy for descriptive qualitative (or quantitative) data analysis whose goal is the development of a set of related but distinct categories within a phenomenon that discriminate across the phenomenon' (Ayres and Knafl, 2008, p. 900). Typically typologies are abstractly categorical rather than hierarchical classifications that offer appealing parsimonious elegance (Ayres and Knafl, 2008, p. 900). However, the typology proposed here pursues a more holistic appreciation of community than conventional classification schemes allow. Excluding the rudimentary conventions where electorates and location define community, the focus here is on community and affects ranging from cosmopolitan (strategic metropolitan engagement), civic-citizen (aggregate individual), and resident-neighbourly levels of community as discreet, overlapping, or contradictory elements. 
Populating this typology begins with a pilot study where data has been gathered from manual (rather than software) content analysis of policy documents and case law. Key policy documents are from Ontario as part of the City of Toronto condominium living consultation process (SWERHUN, 2014, hereafter CCRR) and the Ontario Condominium Act Review (hereafter OCAR 2013a, 2013b; 2014). Sample case law from the Victorian Owners Corporation Tribunal (VCAT) was also analysed using content analysis to open up dynamic understandings rather than closed classification systems. From named data sources and leading MOP literature, key MOP issues have been assembled. These issues may be unique to the Ontarian and Victorian condo experiences. Yet, condo laws and policy exhibit recognisable international trends as they influence and are influenced by policy mobility and domestication abroad.

The presented typology frames and characterizes a powerful narrative that can be drawn from the analysis of the legal and policy documentation. It adds to knowledge on condo community, and further identifies and serves the needs of condo communities and wider metropoles. Findings from the study strive to identify issues that the condo community face, on a daily basis, as well as more broadly. This process gains a deeper understanding of, who comprises the condo community and what are their on-going strategic and everyday needs for socially sustainable and just co-existence. Canadian classifications of issues evolved over the course of law reform consultation. Stage One OCAR (2013b, p.6) used a wide and rich definition of community and stakeholder relationships within a 'framework' and 'administrative' Act based on community building (rather than an enforcement) approach where consulted 'Residents listed seven values for a revised Act: well-being; fairness; informed communities, responsiveness; strong communities; financial sustainability; and effective communication. In the Stage Two report (OCAR, 2013a, p.5) values and issues were distilled into 5 working group units (see Table 1). These themes clearly concern key social sustainability elements conditioning MOP community. However, unsurprisingly, they are plainly classification systems around aspirational and hot topics towards specific elements of law reform fitting a heterogeneous public. Consequently, we pursue a more restrictive typology (Doty and Glick, 1994). This allows for 'recommendation[s] for future research' (O'Raghallaigh et al., 2012, p.101), and advancing extant classifications of MOP community issues in law and literature (Douglas et al., 2009).

Table 1: Hotspot socio-legal MOP issues as classified in Ontario, Canada (OCAR community consultation) and New South Wales, Australia (as surveyed by City Futures Research Centre).

\begin{tabular}{|l|l|}
\hline OCAR Stage One: common condo issues & City Futures Research Centre 2012 survey: strata sector issues \\
\hline \multicolumn{1}{|c|}{ Adapted from OCAR, 2013b: 7} & Adapted from Easthope, Randolph and Judd, 2012, p. 2-5 \\
\hline Governance: board training and support & $\begin{array}{l}\text { Governance in strata: poor owner knowledge; variable board } \\
\text { performance; slow painful decision processes; role confusion }\end{array}$ \\
\hline Dispute Resolution: better education and rules & $\begin{array}{l}\text { Managing buildings: building defects; design problems; lots } \\
\text { and commons boundary confusion; responsibility for repair }\end{array}$ \\
\hline Financial Management: reserve funds & $\begin{array}{l}\text { Managing money: poor budgeting for repairs; continued } \\
\text { developer influence; strata levy levels; sinking fund benchmarks }\end{array}$ \\
\hline Consumer Protection: plain language at sales & $\begin{array}{l}\text { Managing people: disputes; informal resolution popular; } \\
\text { unresolved disputes; critical interpersonal relationships and } \\
\text { skills }\end{array}$ \\
\hline Condominium Manager Qualifications & $\begin{array}{l}\text { Managing information: owner/board difficulties getting } \\
\text { information at/since purchase; limited information sources }\end{array}$ \\
\hline Issues Outside the Act & $\begin{array}{l}\text { Compilation of ranked top disputes in strata scheme survey of } \\
\text { owners (O), Executive committee (E) and Managing agent (M) }\end{array}$ \\
\hline property taxes & $\begin{array}{l}\text { Adapted from Easthope, Randolph and Judd, 2012, p. 87 } \\
\text { Top disputes issues: }\end{array}$ \\
\hline
\end{tabular}




\begin{tabular}{|l|l|l|l|}
\hline & insurance rates & Parking & $\mathrm{O} 1, \mathrm{E} 2, \mathrm{M} 2$ \\
\hline & tenant rights and responsibilities & Breaking by-laws & O2, E4, M3 \\
\hline & industry trends & Noise & O3, E3, M1 \\
\hline \multirow{2}{*}{ Power imbalances within the sector } & Rubbish & O4, M4 \\
\hline \multirow{2}{*}{} & Repairs and maintenance of common property & O5 \\
\cline { 2 - 3 } & Use'of common property & E1, M5 \\
\cline { 2 - 3 } & Renovations within an individual owner's lot & E5, O6 \\
\hline
\end{tabular}

Table 1 data helped establish a reference framework for analysing key MOP issues. Planning and political theory helped differentiate between the typologies outlined below. Specifically, the following subsections build up a theory-building typology for formally recognising and reproducing 'community'. Community is differentiated as an affective performance across MOP governance contexts: cosmopolitan, civic-citizen, and resident-neighbourly. This novel approach builds towards a typological theory of community from analysing key condo issues both known and freshly presented here. This innovation leverages the complexity of typological theories (over 'traditional bivariate or interaction theories') from 'incorporat[ing] multiple levels of theory' and scales of practice (Doty and Glick, 1994, p.232). These ideal hybrid-types are deliberately finite in their account of often-simultaneous community affects determining alternative dispute resolution remedies, addressing neighbourhood and metropolitan NIMBY-ism in urban consolidation, and bridging the critical policy and civic gap regarding limited but aspirational knowledge about vertical-tenured community characteristics in and beyond (case) law and land-use planning. This becomes pressing as MOP urbanism is more pervasive in inner cities than traditional suburban subdivision: 'today, condominiums account for half of all new homes built in Ontario' (OCAR, 2013b, p. 6). Three typologies are defined and illustrated as first order types of community in governance context.

\section{Resident-Neighbourly}

This type of performative construct emphases everyday MOP living including the (in)formal private-public interface of the home and common property. Resident-neighbourly learning to coexist, manage, and be managed by property managers in MOP requires contingent and mutual learning of a legal, collective, informal, and cultural nature. Day-to-day care and administration of the common areas in condominiums is looked after by home owners association. (in Victoria called the Owners Corporation) often in conjunction with professional condo property managers (Douglas and Leshinsky, 2012). Managers provide the necessary expertise in day-to-day management, the running of meetings and complying with regulatory requirements under relevant legislation. The committee of members are normally elected at the annual general meeting (AGM) of the owners corporation. The number of votes held by an individual lot owner is determined by owner lot entitlement that is based on the relative value of that lot owner's property. This measure stands proportional to a member's lot liability for levies. These cover insurance, maintenance, repairs and management of the common property (Leshinsky and Libbis, 2008). Living in close proximity may engender cohesion or disputes due to conflicts over rules or by-laws.

The resident-neighbourly types of MOP conflict issues varies (Easthope and Randolph, 2009) and may arise between owners/occupiers and service providers. Australian research (in Queensland) into the apartment owners experience of living in a large apartment development found owners in conflict with the caretaker and the property manager over the letting of apartments to tourists (Fisher and McPhail, 2014). These authors found that residents were largely dissatisfied with the dispute resolution processes available to them to deal with this and other concerns (p. 11). In a further study that consulted 1550 individuals involved with 
owners corporations, the major areas of conflict (refer Table 1) related to parking (61\%), breaking of by-laws (59\%) and noise (50\%) (Easthope et al., 2012). US and Australian urban policies increasingly tend to an integrated approach with inter-linked material and social elements advances social sustainability in the local neighbourhood scale (Dempsey, Bramley, Power, and Brown, 2011, p 136). The necessity for plain language education and power redress around private commons issues may extend to wider public commons as captured in the second ideal community type.

\section{Civic-Citizen}

This type of performative construct comprises the societal public(collective) and private(individual) interface legally defining community and citizenship. The agency and formalities attending (re)forming critical legal regulatory mechanics for MOP living include the private-public interface of the sovereign territory and private capacity, and regulating formally defined residential community within national law. As MOP urbanism becomes more pervasive in Western low-density cities, outdated legislation and changing MOP community character and identity requires attention. The OCAR $(2013 \mathrm{a}, 2013 \mathrm{~b}, 2014)$ and CCRR (2014) documentation led with a wide mandate to include community to address this civic-citizen interface with MOP. Documents prepared from this process were interrogated using content analysis; followed by a codification of condo issues that arose in relation to condo living in Ontario. The first stage of the ongoing OCAR was completed in early 2013 and identified many shortcomings in the provinces' condominium legal system. As part of the process to ascertain these deficiencies, participants, drawn from across the condo sector, were engaged and they proposed options for improvement and highlighted areas of agreement and differences of opinion (OCAR, 2013, p. 5). In Stage Two, five working groups were set up and these represented a "broad cross-section of interests" (OCAR, 2013, p. 5). A 12-member panel of experts also provided "sober second thought" (OCAR, 2013, p. 5). The CCRR (2014) entailed a two-phase public consultation process (January 2013) to engage people in a range of issues related to city planning and condo living. Stakeholder and public engagement processes help identify key issues faced by condo residents that overlap with a cosmopolitan typology.

\section{Cosmopolitan}

This type of performative construct includes the diverse assemblage of communities comprising a city-region that shapes and is shaped by global capitalist development enabling condo-ism unevenly expressed in the built-form, NIMBY-neighbourhood resistance to MOP high-rise, and the private-public interface of the metropolitan and even international crossborder community. This construct attests to the manner in which planners and policy makers recognise community and communities and then seek effective and morally acceptable intervention. Ontarian reform positively characterises the top-down range and expectations of community as a collective public over the private MOP community. By contrast, Victorian case law provides extreme insight into the conflicts of community often over commons issues, which offer contribution to a greater understanding of engaging the condo community in public decision-making. Such issues extend beyond residential disputes over private commons. They enable cross-jurisdictional and inter-neighbourhood lessons from strategic planning for intensification and amalgamation in metropolitan planning (Mouat and Dodson, 2014). Areas for further research include the heterogeneity and equity in (re)shaping the cosmopolitan expression of (changing) community: for example, addressing the sense of community in the context of renters and owners (Hulse, 2012), multicultural contexts (Barbieri et al., 2014), and socio-spatial inequalities and social cohesion between 
neighbourhoods (Cassiers and Kesteloot, 2012) and between arrivals contra those being displaced (Burns, Lavoie, and Rose, 2012) in condo-ism.

In summary, the relationships between these three 'first order' types recognise key differentials of community aiding theory-building and empirical testing against publically available registers of community, expected community capacity and agency, and hot points in MOP intensified urbanism. 'Actual [communities] may be more or less similar to an ideal type, but they should not be assigned to one of the ideal types in the typology' (Doty and Glick, 1994, p. 233 [original emphases]). Critically, to examine ascribed community affect in combination with key issues alone requires content analysis based on current research and documents for stronger comparative analysis.

Comparative analysis: reviewing legal instruments of community affect towards social sustainability

The typology and content analysis showcase the critical policy and civic gap regarding the limited knowledge about vertical-tenured community characteristics. This cross-tabular analysis reveals three pillars of MOP community governance: harmonious high-rise living, residential-neighbourhood interface, and metropolitan community engagement. The need to be better recognised differentially and in combination reflects the internal/external and (in)formal dimensions of the ideal typology sets. Thus the paper analyses Canadian law reform proposals and responses with Victorian case law deriving five key sub-classifications - technical management, legal regulation, extra-legal issues, civic capacity, and communitycity relations - cross-cutting the typologies. In further analysis these might account for alternative dispute resolution, addressing neighbourhood and metropolitan NIMBY-ism in urban consolidation. A more robust understanding of MOP issues can assist in aligning community needs to wider desirable social infrastructure and social sustainability outcomes.

Sub-classification allows easier comparison between jurisdictions and contexts for policy mobility and mobilization: Table 2 below lists the key MOP issues drawn from the Ontario engagement exercises (ODCS, 2012, OCAR, 2013a, 2013b, 2014 and CCRR, 2014); Table 3 then lists key MOP issues derived from the Victorian case law. The analysis of the key MOP issues from the various data sets was an exploratory step towards linking social sustainability to the context of condo living. The Ontario data allowed for a macro approach to understanding key MOP issues whereas the Victorian data was more limited in the types of MOP issues it raised. Importantly, the data sets themselves offer distinctive yet comparative opportunities - with both contributing to a broader perspective on a very elusive whole: who is the condo community and how does community work to serve their needs? ${ }^{2}$ Working backwards from how conflict and case law exemplified needs, certain overlapping threads were evident from both data sets which allows for further opportunities to explore real community condo needs in coexistence and more broadly, infrastructure needs.

Table 2 is a summary of the key MOP issues from CCRR (2014), ODCS (2012) and OCAR (2013a, 2013b, 2014) engagement processes. For each MOP issue, an assessment was made as to whether they were the concern of the home owners association (HOA) or the municipal or other agency (for example, Province). This assessment is exploratory and introduced the reflective notion that micro issues faced by residents in MOP are representative of broader land-use planning and infrastructure concerns. So, for instance, CCRR and OCAR processes saw stakeholders ask for more condo education tools. This is an issue relevant to the HOA,

${ }^{2}$ This sets aside for now (due to space restrictions) critical questions about the constitution and succession of communities in newly built and existing MOP. 
the City of Toronto and to the Province of Ontario. Another issue to arise was the call for more public open space. To satisfy this issue raised by condo residents, the City might mandate more public open space within developments (private public open space) as well as provide more opportunity for public parks and parklets being available to the broader Toronto community. Such outcomes act out how MOP issues meet the broader public land-use and development realm.

Table 2: Key MOP issues classified from policy documents and stakeholder impact as identified from CCRR (2014) and OCAR $(2013 a, 2013 b, 2014)$

\begin{tabular}{|c|c|c|c|}
\hline \multicolumn{2}{|l|}{ Key MOP issue } & \multirow{2}{*}{\begin{tabular}{|l|}
$\begin{array}{l}\text { Home owners } \\
\text { association }\end{array}$ \\
$\mathrm{X}$ \\
\end{tabular}} & \multirow{2}{*}{$\begin{array}{l}\text { Municipal } \\
\text { /Other } \\
\mathrm{X}\end{array}$} \\
\hline Technical Management & Bike ownership & & \\
\hline & Bike parking around condo developments & $\mathrm{X}$ & $\mathrm{X}$ \\
\hline & Defects (Tarion) & $\mathrm{X}$ & $\mathrm{X}$ \\
\hline & Infrastructure concerns for areas of high growth & $\mathrm{X}$ & $\mathrm{X}$ \\
\hline & More accountability with funds management & $\mathrm{X}$ & $\mathrm{n} / \mathrm{a}$ \\
\hline & Parking spots and accessibility & $\mathrm{X}$ & $\mathrm{X}$ \\
\hline & Pet ownership & $\mathrm{X}$ & $\mathrm{X}$ \\
\hline & Shared visitor parking spots & $\mathrm{X}$ & $\mathrm{n} / \mathrm{a}$ \\
\hline & Smoke free rules & $\mathrm{X}$ & $\mathrm{X}$ \\
\hline & Stopping and delivery space & $\mathrm{X}$ & $\mathrm{X}$ \\
\hline & Storage space & $\mathrm{X}$ & $\mathrm{n} / \mathrm{a}$ \\
\hline \multirow[t]{7}{*}{ Legal Regulation } & Consumer protection & $\mathrm{X}$ & $\mathrm{X}$ \\
\hline & Dispute resolution & $\mathrm{X}$ & $\mathrm{X}$ \\
\hline & Financial management & $\mathrm{X}$ & $\mathrm{n} / \mathrm{a}$ \\
\hline & Planning done on building by building basis & $\mathrm{X}$ & $\mathrm{X}$ \\
\hline & Property management & $\mathrm{X}$ & $\mathrm{X}$ \\
\hline & Tall buildings guidelines & $\mathrm{n} / \mathrm{a}$ & $\mathrm{X}$ \\
\hline & Safety & $\mathrm{X}$ & $\mathrm{X}$ \\
\hline \multirow[t]{6}{*}{ Extra-Legal Issues } & Affordable housing & $\mathrm{X}$ & $\mathrm{X}$ \\
\hline & Flexible unit walls to grow or diminish apartments & $\mathrm{X}$ & $\mathrm{X}$ \\
\hline & Improved retail space & $\mathrm{X}$ & $\mathrm{X}$ \\
\hline & $\begin{array}{l}\text { Mid size buildings and high rise differing amenities } \\
\text { and needs }\end{array}$ & $\mathrm{X}$ & $\mathrm{X}$ \\
\hline & $\begin{array}{l}\text { Mix of unit types: } \\
\text { Housing form, tenure and affordability }\end{array}$ & $\mathrm{X}$ & $\mathrm{X}$ \\
\hline & $\begin{array}{l}\text { More parks and better transit } \\
\text { Public space benefits } \\
\text { Sidewalks, benches, social gathering spaces etc. } \\
\text { Active transportation, street trees, urban design }\end{array}$ & $\mathrm{X}$ & $\mathrm{X}$ \\
\hline \multirow[t]{4}{*}{ Civic Capacity } & Condo education materials & $\mathrm{X}$ & $\mathrm{X}$ \\
\hline & Establish overriding province Condo office & $\mathrm{X}$ & $\mathrm{X}$ \\
\hline & Governance & $\mathrm{X}$ & \\
\hline & $\begin{array}{l}\text { OMB adjudication process has approvals overriding } \\
\text { City Planning approach }\end{array}$ & $\mathrm{n} / \mathrm{a}$ & $\mathrm{X}$ \\
\hline $\begin{array}{l}\text { Community-City } \\
\text { Relations }\end{array}$ & $\begin{array}{l}\text { Participants want to play a greater role in planning } \\
\text { neighbourhoods and communities }\end{array}$ & $\mathrm{X}$ & $\mathrm{X}$ \\
\hline
\end{tabular}

$\mathrm{X}=$ relevant issue

$\mathrm{n} / \mathrm{a}=$ Not applicable

Table 3 lists key MOP issues identified using content analysis from the sample of Victorian court judgments (2011-2014). The types of issues as the subject of the litigation (rather than outcomes) from the court hearings were of prime concern. Table 3 provides an assessment basis for understanding how condo stakeholders were impacted in performative and relational elements relating to disputes. This assessment was based on an analysis of who were the plaintiffs and defendants in the legal proceedings. Further, the authors assessed whether MOP 
issues were relevant to the development itself or more broadly land-use planning and infrastructure concerns for local and state government (similar to the earlier exercise noted in Table 2, above). Some issues, such as noisy neighbours and the unlawful construction of structures on common/shared property was both a HOA issue, a municipal land-use planning matter, and crossed all three typologies. In Victoria, the alteration of common property boundaries are a HOA matter as well attracting legal and public policy concerns from the Land Victoria, the state government agency handling land title registration. Land-use planning and disputes around shared/common area issues are indicative of MOP matters being reflective of larger land-use planning and infrastructure community needs especially in highly-regulated planning systems such as Victoria (Legacy et al., 2014).

Table 3: Key MOP issues from sample State of Victoria, Australia, case law 2011-2014

Table 3: Key MOP issues from sample State of Victoria, Australia, case law 2011-2014
\begin{tabular}{|l|l|l|l|}
\hline Key MOP issue & $\begin{array}{l}\text { Home owners } \\
\text { association }\end{array}$ & $\begin{array}{l}\text { Municipal/ } \\
\text { Other }\end{array}$ \\
\hline Technical Management & $\begin{array}{l}\text { Repair and maintenance of common/shared } \\
\text { property and services }\end{array}$ & $\mathrm{X}$ & $\mathrm{n} / \mathrm{a}$ \\
\hline & Fee arrears & $\mathrm{X}$ & $\mathrm{n} / \mathrm{a}$ \\
\hline Legal Regulation & Alteration of common property boundaries & $\mathrm{X}$ & $\mathrm{X}$ \\
\hline & Carrying on a business in a residential lot & $\mathrm{X}$ & $\mathrm{X}$ \\
\hline & Health, safety and security of residents & $\mathrm{X}$ & $\mathrm{X}$ \\
\hline & $\begin{array}{l}\text { Car parking - improper use of private car spot by } \\
\text { resident }\end{array}$ & $\mathrm{X}$ & $\mathrm{n} / \mathrm{a}$ \\
\hline & Noise (including from pets) & $\mathrm{X}$ & $\mathrm{X}$ \\
\hline & $\begin{array}{l}\text { Unlawful construction on common/shared } \\
\text { property }\end{array}$ & $\mathrm{X}$ & $\mathrm{X}$ \\
\hline $\begin{array}{l}\text { Community-City } \\
\text { Relations }\end{array}$ & $\begin{array}{l}\text { Peaceful enjoyment of common/shared property } \\
\text { and services }\end{array}$ & $\mathrm{X}$ & $\mathrm{X}$ \\
\hline
\end{tabular}

$\mathrm{X}=$ relevant issue

$\mathrm{n} / \mathrm{a}=$ not applicable

Comparative analysis clearly indicates common and distinctive key MOP issues impact and influence community affect. Findings from this study have allowed for further insight into the real issues facing MOP communities. Together they help shape a contribution to the dearth in knowledge of key MOP issues and community mobility, mobilization, and domestication. In terms of the specific findings from the data sets, in both cities, issues such as pet and bike ownership issues were a common issue, suggesting perhaps that MOP communities both desire and require public open space either in or around MOPs to exercise their dogs or park bikes. Concerns for safety were also shared, both within the building, and more broadly relating to common areas around buildings. Parking, bikes and safety concerns are all matters that impact privately within a condo complex yet, more broadly, as familiar and significant municipal social infrastructure issues. Insights from CCCR (2014) provided further rich data indicative of equitable community aspirations ranging from small-scale needs, to others such as the desire for more family sized and affordable MOP housing. The case law from the state of Victoria, Australia, identified concern for matters valued by all communities including peaceful enjoyment of common areas. The Ontario law reform documentation (ODCS, 2012, OCAR, 2013a, 2013b, 2014) identified that participants want to play a greater role in planning their neighbourhoods and communities. Issues like these cut to the socio-cultural heart of community living and social sustainability, both within MOP and cities. Affordable and adaptable housing, parks, sidewalks and other shared public spaces will become more important to citizens everywhere as MOP numbers increase and urbanism intensifies. Hence, reciprocal learning between MOP jurisdiction, within and between physical-legal MOP 
structure and extending into broad civic life are important in this framework, as is the discussion on the use of the commons for community in the $21^{\text {st }}$ century.

\section{Conclusions: hard lessons and softer learnings}

Increasing knowledge about community and its needs can promote greater social and sustainable equitable outcomes. In turn this enhances equitable opportunities for citizens in their cosmopolitan and cross-border co-existence (Legacy and Leshinsky, 2013, Mouat and Dodson, 2014). It will also raise the priority and practical wisdom of knowing who constitutes, performs and governs MOP community. The article advances a theory-building typology as an innovative and interdisciplinary approach to inform academic and policy practice concerning social sustainability exemplified by the often, simultaneous characterizations and conflicts, of community in planning, law, and political theory. While it opens up fruitful pathways to assist in recognising community in lay and professional terms, this approach is not a panacea. Further targeted global empirical evidence and theoretical development is required to understand the impact of MOP living at both micro and macro scales of governance and sustainability. That is, within the constitution and socio-legal reproduction of MOP community itself, and the implications for local, metropolitan, and national land-use planning processes and infrastructure requirements. This will ensure morally acceptable policy responses as MOP governance and more attuned municipal and national government understanding of community precinct level needs and desires (whether in clusters of private MOP and/or social housing apartment development areas). Not to mention the plethora of expectations on community coded in suites of statutes (environmental, infrastructural, and planning, for example) concerning consultation, appeal rights, and amenity, for example. A more robust understanding of community is essential, therefore, to gain greater insight into the socio-legal aspects of MOP living which in turn, can stimulate policy makers, municipalities, and homeowner associations to effect greater equitable and sustainable outcomes for stakeholders in multi-unit developments (McKenzie, 1994; 1998).

Whilst the literature is growing on MOP in areas such as densification, social technical tools to enhance environmental sustainability and governance and dispute resolution, less has been said on the hard lessons. It is here where engagement definitions, processes, and tools play an essential role. Namely, seeking more sophisticated recognition of community in land-use planning and property instrumentality will ensure differential social sustainability needs are being recognized and addressed as globally mobile policies are domesticated. Community engagement exercises such as those undertaken by CCRR in Toronto, as well as the endeavours under the OCAR are fundamental tools for broader recognition of community and gaining knowledge on community needs and issues. Further, through creating a plain language typology overlaying conventional academic and legal classifications of key MOP issues and challenges, patterns can be drawn to understand and deliberate over the diversity of social sustainability concerns, desires and needs for MOP residents. These complement current reforms and offer innovative transformative possibilities for public reproduction of community and harmonious governance.

Soft learning from findings reported allow for rich(er) insights into the socio-legal issues that face residents in their daily lives and the associated performative elements of harmonious 
MOP living. Gathering evidence can build on existing findings in the form of interviews with MOP stakeholders, gauging views from social media tools (like Facebook pages and condo blogs (Kern, 2015), and group metropolitan discussion forums (Dowling et al., 2010; Kenna and Stevenson, 2013). This article raises awareness for key MOP issues and the importance of engaging MOP communities in transparently and democratically realizing their desires and needs. This is important not only for helping to assess how MOPs themselves can effect change but also addresses broader precinct and city social sustainability ambitions. It is anticipated that through advancing the discussion beyond (key) MOP issues, MOP communities themselves can be better identified, educated, activated, and aligned for equitable (social) infrastructure provision. This comes through engaging with the community both as it actually and aspirationally exists in intensified $21^{\text {st }}$ century global urbanism. 


\section{References}

Ariff, N. R. M. and Davies, H. (2011), "Multi-owner low-cost housing management in Malaysia", International Journal of Housing Markets and Analysis, Vol. 4 No. 3, pp. 268-289.

Ayres, L. and Knafl, K. (2008), "Typological Analysis", Given, L.M. (Ed.), The SAGE Encyclopaedia of Qualitative Research Methods, Vol 2, Sage, Thousand Oaks, CA, pp. 900-901.

Bailey, N. (2010), "Understanding Community Empowerment in Urban Regeneration and Planning in England", Planning Practice and Research, Vol. 25 No. 3, pp. 317-332.

Barbieri, I., Zani, B. and Sonn, C. (2014), "Meanings of community in contexts of multiculture" Journal of Community Psychology, Vol. 42 No. 8, pp. 980-996.

Blandy, S., Dupuis, A. and Dixon, J. (2010), Multi Owned Housing: Law Power and Practice, Ashgate, Farnham Surrey, UK.

Burns, V. F., Lavoie, J.P. and Rose, D. (2012), "Revisiting the Role of Neighbourhood Change in Social Exclusion and Inclusion of Older People", Journal of Aging Research, Vol. 2012, pp. 1-12. Canada's Public Policy Forum. OCAR (2013a), Growing Up: Ontario's Condominium Communities Enter A New Era (Condominium Act Review: Stage Two Solutions Report). Public Policy Forum. Ottawa.

Canada's Public Policy Forum. OCAR (2013b), Ontario's Condominium Act Review: Stage One Findings Report. Public Policy Forum. Ottawa.

Canada's Public Policy Forum. OCAR (2014), A Case Study of Ontario' Condominium Act Review. Public Policy Forum. Ottawa.

Cassiers, T. and Kesteloot, C. (2012), "Socio-spatial Inequalities and Social Cohesion in European Cities", Urban Studies, Vol. 49 No. 9, pp. 1909-1924.

Davies, A. and Atkinson, M. (2012), "The Moderating Influence of Property Legislation on Planning Policy and Urban Form", Urban Studies, Vol. 49 No. 16, pp. 3479-3494.

Dempsey, N., Bramley, G., Power, S. and Brown, C. (2011), "The social dimension of sustainable development", Sustainable Development, Vol. 19 No.5, pp. 289-300.

Doty, D. H. and Glick, W. H. (1994), "Typologies as a Unique Form of Theory Building", The Academy of Management Review, Vol. 19 No. 2, pp. 230-251.

Douglas, K. and Leshinsky, R. (2012), "Pre-action dispute resolution under the Owners Corporation Act 2006", Australian Property Law Journal, Vol. 20 No. 3, pp. 224-236.

Douglas, K., Leshinsky, R. and Goodman, R. (2009), "Mediating the neighbors", Law Institute Journal, Vol. 83 No. 6, pp. 48-50.

Dowling, R., Atkinson, R. and McGuirk, P. (2010), "Privatism, Privatisation and Social Distinction in Master-Planned Residential Estates", Urban Policy and Research, Vol. 28 No. 4, pp. 391-410. Dredge, D. and Coiacetto, E. (2011), "Strata Title: Towards a Research Agenda for Informed Planning Practice", Planning Practice and Research, Vol. 26 No.4, pp. 417-433.

Easthope, H. and Randolph, B. (2009), "Governing the Compact City: The Challenges of Apartment Living in Sydney, Australia”, Housing Studies, Vol. 24 No. 2, pp. 243-259.

Easthope, H., Randolph, B. and Judd, S. (2012), Governing the Compact City: The role and effectiveness of strata management. City Futures Research Centre. Sydney. Retrieved from https://www.be.unsw.edu.au/sites/default/files/upload/research/centres/cf/newsarchive/2011/Governin $\mathrm{g}$ the_Compact_City_FINAL_REPORT.pdf.

Easthope, H. and Tice, A. (2011), "Children in Apartments: Implications for the Compact City", Urban Policy and Research, Vol. 29 No. 4, pp. 415-434.

Fainstein, S. (2010), The Just City, Cornell University Press, Ithaca.

Fincher, R. (2007), "Is High-rise Housing Innovative?", Urban Studies, Vol. 44 No.3, pp. 631-649.

Fincher, R. and Iveson, K. (2008), Planning and Diversity in the City, Palgrave MacMillan, New York.

Fisher, R. and McPhail, R. (2014), Residents' Experiences in Condominiums: A Case Study of Australian Apartment Living. Housing Studies, Vol. 29 No. 6, pp. 781-799.

Flyvbjerg, B. (2004), "Phronetic planning research: theoretical and methodological reflections", Planning Theory and Practice, Vol. 5 No. 3, pp. 283-306.

Gleeson, B. (2004), "Deprogramming Planning: Collaboration and Inclusion in New Urban Development", Urban Policy and Research, Vol. 22 No. 3, pp. 315-322. 
Goodman, R. and Douglas, K. (2010), "Life in a Master Planned Estate-Community and Lifestyle or Conflict and Liability?", Urban Policy and Research, Vol. 28 No. 4, pp. 451-469.

Grosvenor, M. and O' Neill, P. (2014), "The Density Debate in Urban Research", Geographical Research, Vol. 52 No. 4, pp. 442-458.

Hopwood, B., Mellor, M, and O’Brien, G. (2005), "Sustainable Development: Mapping Different Approaches", Sustainable Development, Vol. 13 No. 1, pp. 38-52.

Horvath, R. J. (2004), "The Particularity of Global Places: Placemaking Practices in Los Angeles and Sydney", Urban Geography, Vol. 25 No. 2, pp. 92-119.

Hulse, K. (2012) The Australian private rental sector: changes and challenges, AHURI Positioning Paper No.149. Melbourne: Australian Housing and Urban Research Institute.

Huston, S. and Darchen, S. (2014), "Urban regeneration", International Journal of Housing Markets and Analysis, Vol. 7 No. 2, pp. 266-282.

Ibrahim, A. (2011), "Designing High-Density Cities", The Town Planning Review, Vol. 82 No. 2, pp. 228-230.

Kenna, T. and Stevenson, D. (2010), 'Negotiating Community Title: Residents' Lived Experiences of Private Governance Arrangements in a Master Planned Estate', Urban Policy and Research, Vol. 28 No. 4, pp. 435-449.

Kenna, T. and Stevenson, D. (2013), "Experiences of 'Community' in a Gated Residential Estate", Geographical Research, Vol. 51 No. 4, pp. 412-423.

Kern, L. (2015) "'This is a mess": Seeking answers in the dark side of Condo-land', presented at the Association of American Geographers Congress, 21-25 April, Chicago, USA

Lees, L. (2012), "Social Mix and the City: Challenging the Mixed Communities Consensus in Housing and Urban Planning Policies", International Planning Studies, Vol. 17 No. 4, pp. 421-423. Legacy C. and Leshinsky R. (2013) "Tools for equitable urban intensification", Built Environment Vol. 39 No. 4, pp. 409-421.

Legacy, C., March, A. and Mouat, C. M. (2014), "Limits and potentials to deliberative engagement in highly-regulated planning systems: norm development within fixed rules", Planning Theory and Practice, Vol. 15 No. 1, pp.26-40.

Leshinsky, R., Condliffe, P., Taylor, E. and Goodman, R. (2012), "What are they fighting about? Research into disputes in Victorian owners corporations", Australasian Dispute Resolution Journal, Vol. 23 No. 2, pp. 112-119.

Leshinsky, R. and Libbis, S. (2008), Owners Corporations in Victoria: A Manual for Owners,

Occupier and Managers, Hybrid Press, Ormond, Vic.
Levy, D. and Sim, Q.-H. (2014), "Why multi-owned housing owners are dissatisfied with the service provided by their management companies in New Zealand", International Journal of Housing Markets and Analysis, Vol. 7 No. 3, pp. 397-416.

Maller, C. and Nicholls, L. (2013), "Encountering the Multiplicity of Community in Planning and Designing New Neighbourhoods", Urban Policy and Research, Vol. 32 No. 1, pp.17-32.

Margerum, R. D. (2011), Beyond Consensus: Improving Collaborative Planning and Management, MIT Press, Cambridge, MA.

Mouat, C. M. and Dodson, J. (2014), "Governance by re-bordering': comparing re-bordering as spatial governance strategy in Auckland, Brisbane/SEQ, Vancouver, London, and Manchester", in Steele, W., Alizadeh, T., Fslami-Andargoli L. and Serrao-Neumann, S. (Eds.), Planning Across Borders in a Climate of Change. Routledge, Brisbane, pp. 107-122

Mouat, C. M. (2010) Rethinking Community in Planning: A review of the role of planners and citizens in building strong communities. PhD. Thesis, Planning, The University of Auckland, New Zealand. O'Raghallaigh, P., Sammon, D. and Murphy, C. (2010), Theory-building using Typologies --A Worked Example of Building a Typology of Knowledge Activities for Innovation. Paper presented at the Proceedings of the 2010 conference on Bridging the Socio-technical Gap in Decision Support Systems: Challenges for the Next Decade. Retrieved 24 March, 2015, from http://search.ebscohost.com/login.aspx?direct=trueanddb=nlebkandAN=342832andsite=ehost-live O'Raghallaigh, P., Sammon, D. and Murphy, C. (2012), "Open innovation and the quest for a theoretical core", Journal of Decision Systems, Vol. 21 No. 2, pp. 101-119. 
Ontario Department of Consumer Services. ODCS (2012), The Condominium Act, 1998: Ontario's Comprehensive Review: June 8, 2012. Retrieved 24 June, 2013, from

http://www.sse.gov.on.ca/mcs/en/Pages/condo_review.aspx

Palmer, J. S. (2014), Seeking systems for sustainable higher-density housing in Australian cities. Paper presented at the World Sustainable Building 2014, Barcelona.

Pløger, J. (2006), "In Search of Urban Vitalis", space and culture, Vol. 9 No.4, pp. 382-399.

Randolph, B. and Tice, A. (2013), "Who Lives in Higher Density Housing?", Urban Studies, Vol. 50

No. 13, pp. 2661-2681.

Rosen, G. and Walks, A. R. (2013), "Rising cities: Condominium development and the private transformation of the metropolis", Geoforum, Vol. 49, pp. 160-172.

Sandercock, L. (2003), Cosmopolis 2: Mongrel Cities of the 21st Century, Continuum, New York. Shaw, M. (2008), "Community development and the politics of community", Community

Development Journal, Vol. 43 No.1, pp. 24-36.

Sherry, C. (2008), "The Legal Fundamentals of High Rise Buildings and Master Planned Estates", Australian Property Law Journal, Vol. 16 No. 1, pp. 1-23.

SWERHUN. (2014), City of Toronto Condominium Consultation Recommendation Report City of Toronto SWERHUN in association with R.E. Millward and Associates Ltd., regional Architects and Halsall Associates. Toronto.

Warr, D. and Robson, B. (2013), “"Everybody's Different': Struggles to Find Community on the Suburban Frontier", Housing Studies, Vol. 28 No. 7, pp. 971-992.

Wolf-Powers, L. (2014), "Understanding community development in a "theory of action"

framework", Planning Theory and Practice, Vol. 15 No. 2, pp. 202-219.

\section{Victorian case law}

Black v Foo (Owners Corporations) [2013] VCAT 1676

Conroy v Owners Corporation Strata Plan 30438 (Owners Corporations) [2014] VCAT 550

Lee v Owners Corporation No. 501391P (Owners Corporations) [2013] VCAT 1942

Owners Corporation RN21199 v Hipworth (Owners Corporation) [2012] VCAT 1306

Owners Corporation PS326519P v May (Owners Corporations) [2013] VCAT 933

Owners Corporation PS425500K v Nova Stargate Pty Ltd (ACN 096721 498) (Owners Corporation) [2011] VCAT 194

Owners Corporation PS331362S v Rhodes (Owners Corporation) [2011] VCAT 642

Owners Corporation PS514657D v Strong (Owners Corporation) [2011] VCAT 877

Paisley v Owners Corporation PS52240 (Owners Corporations) [2013] VCAT 1739

Wilkinson v Owners Corporation SP0282875 (Owners Corporations) [2013] VCAT 1738 